\title{
Kepribadian Tipe A dan Risiko Hipertensi pada Orang Dewasa
}

\section{Type A Personality and Risk of Hypertension among Adult People}

\author{
Nancy Chitrayana, Benedicta Feby, Yunita Lauren, Marcella Erwina Rumawas, Valentinus Budi Kidarsa
}

Fakultas Kedokteran Universitas Tarumanegara Jakarta

\begin{abstract}
Abstrak
Hipertensi merupakan salah satu penyakit yang paling banyak terjadi di Jakarta. Ciri kepribadian tipe A, yaitu tampak selalu sibuk, terburu-buru, tidak sabar atau mudah marah, tampak pada beberapa pasien hipertensi. Penelitian potong lintang ini bertujuan untuk mengetahui hubungan antara kepribadian tipe A dengan hipertensi. Sebanyak 64 responden, yang usia $>30$ tahun dan tidak sedang dalam pengobatan dengan antihipertensi, dipilih secara konsekutif di antara pengunjung Puskesmas Kelurahan Joglo-II antara 30 April - 5 Mei 2012. Tekanan darah diukur sesuai dengan protokol standar. Informasi tentang kepribadian dan faktor-faktor risiko yang lain dikumpulkan dengan wawancara menggunakan kuesioner. Analisis statistik menggunakan prosedur generalized linear model. Ditetapkan batas kemaknaan 0,05. Dari 64 responden, 36 orang $(56,3 \%)$ mempunyai kepribadian tipe A dan 22 orang $(34,4 \%)$ menderita hipertensi. Hipertensi didapatkan pada 13 dari 36 responden $(36,1 \%)$ dengan kepribadian tipe A dan 9 dari 28 responden $(32,1 \%)$ tanpa kepribadian tersebut. Pada usia dan jenis kelamin yang disetarakan, risiko hipertensi lebih besar secara bermakna 1,3 kali pada responden dengan kepribadian tipe A dibandingkan dengan mereka dengan kepribadian tipe non- $\mathrm{A}(\mathrm{PR}=1,3$; nilai $p=0,003)$. $\mathrm{Pe}$ nambahan faktor-faktor risiko hipertensi yang lain melemahkan asosiasi, tetapi tidak mengubah kemaknaan statistik ( $P R=1,2$; nilai $p=0,04)$. Identifikasi tipe kepribadian disarankan sebagai bagian dari pencegahan hipertensi.
\end{abstract}

Kata kunci: Hipertensi, kepribadian tipe A, orang dewasa

\section{Abstract}

Hypertension is one of the major diseases in Jakarta. The typical characteristics of type A personality include being busy, in hurry, impatient and irritable, were shown in some hypertensive patients. This cross-sectional study examined the relationhip between type A personality and hypertension. Sixty-four respondents (age $>30$ years and were not on antihypertensive medication), were consecutively selected among patients attending
Joglo-II Primary Health Center, between April 30 - May 5, 2012. Blood pressures were measured according to the standard protocol. Information on personality and other risk factors of hypertension were colected using interview-based questionnaires. Analyses were done using the general linear model at the significant level of $5 \%$. Of 64 respondents, 36 respondents $(56.3 \%)$ had type A personality and 22 respondents (34.4\%) had hypertension. Hypertension were diagnosed in $13(36.1 \%)$ out of 36 respondents with type-A personality and 9 (32.1\%) out of 28 respondents with non-A type personality. Adjusted for age and sex, the risk of hypertension was 1.3 significantly higher in respondents who were type A personality than in those who were not $(P R=1,3 ; p$ value $=0.003)$. Further adjustment for other risk factors for hypertension attenuated the association, but remained significant $(P R=1,2 ; p$ vallue $=0,04)$. Identification of personality type is advisable as part of the efforts for preventing hypertension.

Keywords: Hypertension, type A personality, adult

\section{Pendahuluan}

Hipertensi adalah faktor risiko utama penyakit kardiovaskuler yang merupakan penyebab utama kematian di seluruh dunia. ${ }^{1}$ Pada tahun 2008, hipertensi diperkirakan menyebabkan 7,5 juta kematian, atau sekitar 12,8\% dari seluruh kematian di dunia. Pada tahun yang sama, prevalensi hipertensi pada orang berusia lebih dari 25 tahun di dunia adalah sekitar $40 \%$. Walaupun jumlah penderita hipertensi di dunia pada periode 1980 - 2008 menurun, pertumbuhan penduduk yang pesat tetap meningkatkan jumlah penderita hipertensi, dari 600 juta pada tahun 1980 menjadi hampir 1 miliar pada tahun $2008 .^{2}$

Alamat Korespondensi: Marcella Erwina Rumawas, Fakultas Kedokteran Universitas Tarumanegara, Jl. Letjen S. Parman No. 1 Grogol Jakarta Barat, 11440, Hp.081280979353,e-mail: marcellarumawas@gmail.com 
Di Asia Tenggara, pada tahun 2008, kasus hipertensi mencakup hampir sepertiga jumlah populasi usia dewasa dan diperkirakan sekitar 1,5 juta orang di Asia Tenggara meninggal karena hipertensi. ${ }^{3}$ Di Indonesia, prevalensi hipertensi pada tahun 2007 mencapai 31,7\% dari total populasi penduduk usia lebih dari 18 tahun.4,5 Angka tersebut lebih tinggi dibandingkan dengan Singapura $(27,3 \%)$, Thailand $(22,7 \%)$, dan Malaysia (20\%). ${ }^{5}$ Pada tahun 2007, sekitar $60 \%$ penderita hipertensi berakhir dengan stroke, sisanya berakhir dengan penyakit jantung, gagal ginjal, dan kebutaan. ${ }^{4}$

Di Jakarta, khususnya di Puskesmas Kelurahan Joglo II, Jakarta Barat, berdasarkan data sepuluh penyakit terbanyak tahun 2011, terdapat 1.434 kasus hipertensi; atau sekitar $12,8 \%$ dari seluruh kasus penyakit di puskesmas tersebut. ${ }^{6}$ Angka tersebut menempatkan hipertensi pada urutan penyakit terbanyak ketiga setelah infeksi saluran pernapasan akut dan gangguan neurotik.

Dari survei awal di Puskesmas Kelurahan Joglo II tersebut diperoleh kesan bahwa banyak pasien hipertensi yang mengaku selalu sibuk, mempunyai kegiatan yang terjadwal, tampak terburu-buru dalam bicara dan berjalan, tidak sabar, mudah marah, serta selalu ingin didahulukan. Karakteristik tersebut tipikal pada orang dengan kepribadian tipe A. Tipe kepribadian dipercaya berpengaruh terhadap hipertensi, selain faktor risiko hipertensi yang umum diketahui seperti usia, jenis kelamin, faktor genetik, obesitas, merokok, dan diet tinggi garam. Oleh karena itu, tujuan penelitian ini adalah untuk mengetahui hubungan antara kepribadian tipe A dengan hipertensi pada orang dewasa di Jakarta.

\section{Metode}

Penelitian ini dilakukan dengan desain studi analitis observasional potong lintang untuk mengetahui hubungan antara kepribadian tipe A dengan hipertensi. Sebanyak 64 responden yang berusia di atas 30 tahun dan tidak mengonsumsi obat anti hipertensi, dipilih dengan cara consecutive nonrandom sampling dari antara pengunjung Puskesmas Kelurahan Joglo II pada tanggal 30 April - 5 Mei 2012. Data mengenai karakteristik kepribadian tipe A dan faktor risiko lainnya dikumpulkan dengan melakukan wawancara dengan menggunakan kuesioner terstruktur. Pengukuran tekanan darah dilakukan dengan menggunakan sfigmomanometer dan stetoskop. Pengukuran berat badan pasien dilakukan dengan menggunakan timbangan berat badan dan tinggi badan dilakukan dengan microtoise. Variabel tergantung adalah hipertensi dan variabel bebas adalah kepribadian tipe A. Responden diklasifikasikan ke dalam kelompok "hipertensi" bila tekanan sistolik $\geq 140 \mathrm{mmHg}$ dan atau tekanan diastoliknya $\geq 90 \mathrm{mmHg}$; dan sebaliknya ke dalam kelompok "normal" bila tekanan darah < 140/ $<90 \mathrm{mmHg}$. Selain itu, responden yang mempunyai karakteristik selalu sibuk dan mempunyai kegiatan yang terjadwal, terburu-buru dalam bicara, makan, dan berjalan, tidak sabar dan mudah marah, ingin melakukan banyak kegiatan dalam satu waktu, kompetitif, dan selalu berusaha untuk menang, sulit menerima kegagalan, selalu ingin didahulukan, jarang bersantai, diklasifikasikan dalam kelompok "kepribadian tipe A"; dan sebaliknya ke dalam kelompok "kepribadian tipe non-A".

Untuk menyatakan perbandingan besarnya risiko hipertensi antara responden dengan kepribadian tipe A dan mereka dengan kepribadian tipe non-A, dihitung nilai risk difference (risiko absolut hipertensi pada responden dengan kepribadian tipe $\mathrm{A}$ ) dan prevalence ratio (risiko relatif hipertensi pada responden dengan dengan kepribadian tipe A). Analisis statistik untuk menguji hubungan antara kepribadian tipe A dan hipertensi dilakukan dengan menggunakan model binary logistic pada prosedur statistik generalized linear model. Usia dan jenis kelamin adalah faktor-faktor perancu potensial yang diuji pengaruhnya terhadap asosiasi antara kepribadian tipe A dan hipertensi. Nilai $\mathrm{p}<0,05$ dinyatakan sebagai adanya asosiasi statistik.

\section{Hasil}

Penelitian ini dilakukan pada 64 responden, 37 orang $(57,8 \%)$ perempuan dan rerata ( \pm simpang baku) usia adalah 45,6 \pm 11,6 tahun. Pada 64 responden didapatkan rerata ( \pm simpang baku) tekanan darah sistolik dan diastolik berturut-turut sebesar $126 \pm 18,8 \mathrm{mmHg}$ dan $80 \pm$ 9,34 mmHg. Dari 64 responden, didapatkan 22 orang $(34,4 \%)$ menderita hipertensi dan 36 orang $(56,3 \%)$ mempunyai kepribadian tipe A.

Responden dengan kepribadian tipe A lebih banyak perempuan, mempunyai rerata tekanan sistolik yang lebih tinggi, lebih banyak yang diklasifikasikan status gizi kurang ataupun gizi lebih, dan memiliki riwayat hipertensi dalam keluarga. Namun, lebih sedikit yang merokok ataupun menyukai diet tinggi garam (Tabel 1). Rerata tekanan diastolik, usia, dan indeks massa tubuh relatif sama pada kelompok kepribadian A dan non-A.

Pada 36 responden dengan kepribadian tipe A, didapatkan 13 orang $(36 \%)$ menderita hipertensi, sedangkan dari 28 responden dengan kepribadian tipe non-A didapatkan 9 orang $(32 \%)$ dengan hipertensi (Gambar 1). Risiko absolut hipertensi berkaitan dengan kepribadian tipe A sebesar 4\%, artinya selisih risiko hipertensi pada responden dengan kepribadian tipe A dan tipe non-A (risk difference $=4 \%$ ). Risiko hipertensi pada responden dengan kepribadian tipe A adalah 1,12 kali lebih besar daripada responden dengan kepribadian tipe non-A (prevalence ratio $=1,12)$.

Pada penelitian ini, risiko hipertensi meningkat 120\% pada responden dengan kepribadian tipe A dibandingkan dengan kepribadian tipe non-A. Secara statistik, hubung- 
Tabel 1. Karakteristik Responden

\begin{tabular}{lll}
\hline Variabel $^{*}$ & Kepribadian tipe A & Kepribadian tipe non-A \\
\hline${\text { Usia (tahun })^{\dagger}}^{\dagger}$ & $45,6 \pm 12,5$ & $45,6 \pm 10,7$ \\
Laki-laki & $13(36,1)$ & $14(50)$ \\
${\text { Tekanan darah sistolik }(\mathrm{mmHg})^{\dagger}}^{\dagger}$ & $129 \pm 19,2$ & $122 \pm 17,6$ \\
${\text { Tekanan darah diastolik }(\mathrm{mmHg})^{\dagger}}^{\dagger}$ & $80 \pm 9,6$ & $80 \pm 9,2$ \\
Berat badan $(\mathrm{kg})^{\dagger}$ & $59,9 \pm 12,4$ & $61,9 \pm 13,7$ \\
Tinggi badan $(\mathrm{cm})^{\dagger}$ & $159,8 \pm 7,2$ & $160,4 \pm 8,3$ \\
Indeks massa tubuh $\left(\mathrm{kg} / \mathrm{m}^{2}\right)^{\dagger}$ & $23,4 \pm 4,1$ & $23,9 \pm 4,1$ \\
Status gizi & & \\
Gizi kurang & $6(16,7)$ & $1(3,6)$ \\
Gizi cukup & $16(44,4)$ & $22(78,6)$ \\
Gizi lebih (obesitas) & $13(36,1)$ & $4(14,3)$ \\
Hipertensi dalam keluarga & $26(72,2)$ & $5(17,9)$ \\
Merokok & $11(30,65)$ & $12(42,9)$ \\
Diet tinggi garam & $14(38,9)$ & $18(64,3)$ \\
\hline
\end{tabular}

Keterangan:

* Nilai adalah jumlah (persentase), kecuali dinyatakan sebaliknya

$\dagger$ Nilai adalah rerata \pm simpang baku

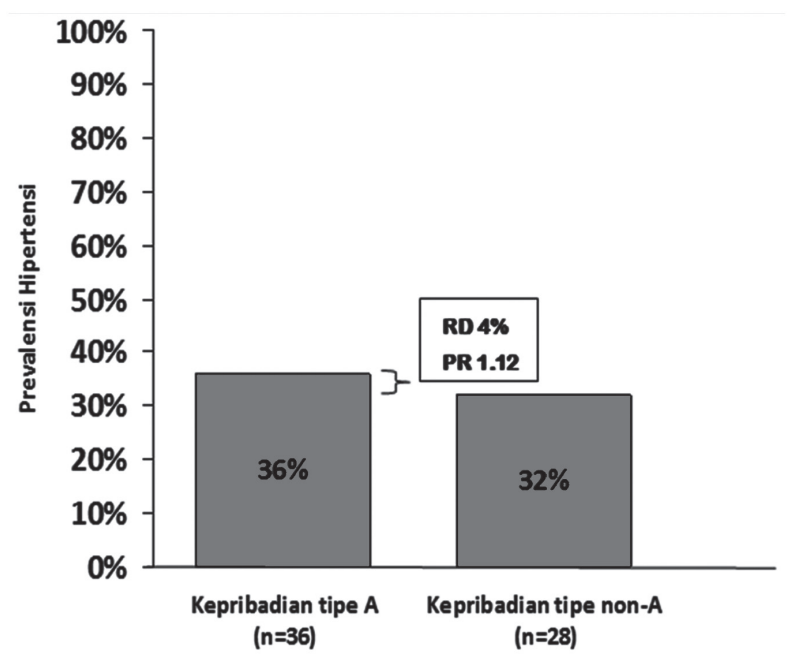

Gambar 1. Perbandingan Besar Risiko Hipertensi antara Responden dengan Kepribadian Tipe A dengan Non-A

Tabel 2. Risiko Hipertensi pada Kepribadian Tipe A

\begin{tabular}{lcl}
\hline Model Statistik* & Prevalence Ratio & Nilai p \\
\hline Model dasar & 1,1 & 0,74 \\
Model 1 & 1,3 & 0,003 \\
Model 2 & 1,2 & 0,04
\end{tabular}

Keterangan:

Model dasar : Kelompok responden dengan kepribadian tipe A dibandingkan dengan kelompok responden tanpa kepribadian tipe A.

Model 1 : Model dasar dengan penyetaraan faktor-faktor risiko hipertensi yang tidak dapat dimodifikasi (usia, jenis kelamin).

Model 2 : Model 1 dengan penyetaraan faktor-faktor risiko hipertensi yang dapat dimodifikasi (riwayat hipertensi dalam keluarga, merokok, diet tinggi garam, indeks massa tubuh).

an antara kepribadian tipe A dengan hipertensi tersebut tidak bermakna $(P R=1,1$; nilai $\mathrm{p}=0,74)$ (Tabel 2$)$. Hubungan tersebut menjadi bermakna setelah faktor risiko umur dan jenis kelamin disetarakan $(P R=1,3$; ni- lai $p=0,003)$. Penambahan faktor risiko riwayat hipertensi dalam keluarga, merokok, diet tinggi garam, IMT pada model yang ada tidak mengubah kemaknaan statistik $(P R=1,2$; nilai $\mathrm{p}=0,04)$.

\section{Pembahasan}

Penelitian ini mendapatkan hubungan kepribadian tipe-A dan hipertensi pada usia dan jenis kelamin yang disetarakan ( $P R=1,3$; nilai $p=0,003$ ). Pasien yang memiliki kepribadian tipe A mempunyai peningkatan kerja sistem saraf simpatis dan hemodinamik tubuh yang memengaruhi denyut jantung dan tekanan darah. ${ }^{7}$ Penelitian eksperimental dan bukti klinis menunjukkan central neural origin dari peningkatan sistem simpatis. ${ }^{7}$

Temuan ini mendukung beberapa penelitian sebelumnya, kepribadian tipe A merupakan faktor risiko independen dari hipertensi. Wawancara terhadap 221 pasien hipertensi dan 221 orang normotensi di Basra, Irak. Kelompok hipertensi sedang dalam pengobatan dengan obat anti hipertensi, dengan kriteria eksklusi apabila pasien hamil, riwayat stroke, infark miokard, dan angina pektoris. Proporsi kepribadian tipe A lebih tinggi pada kelompok hipertensi dibandingkan kelompok yang normo tensi $(57,5 \%: 24,9 \%)$, dengan risiko hipertensi empat kali lebih besar pada responden dengan kepribadian tipe A dibandingkan dengan yang tanpa kepribadian tersebut $(\mathrm{OR}=4,1 ; 95 \% \mathrm{CI}=2,7-6,1) .{ }^{8}$ Penelitian kohort yang membandingkan prevalensi kepribadian tipe A pada 109 pasien hipertensi dan 109 subjek normotensi pada usia, gender, etnik, serta pekerjaan sudah disetarakan. Diagnosis hipertensi ditentukan melalui lima kali pemeriksaan selama lima bulan. Dari hasil pemeriksaan, didapatkan kepribadian tipe A lebih banyak pada kelompok hipertensi $(78 \%)$ daripada kelompok normotensi $(60 \%){ }^{9}$

Hingga kini, belum banyak penelitian terbaru mengenai kepribadian tipe A. Sebanyak 47 laki-laki dengan tipe kepribadian A dan B diberikan dua stressor psikososial (waktu reaksi dan stroop color word test) dan satu stressor fisik (isometric hand grip). Responden dengan tipe kepribadian tipe A mempunyai respons tekanan darah diastolik yang lebih besar terhadap ketiga stressor dibandingkan tipe kepribadian B. ${ }^{10}$ Pengukuran kadar norepinefrin dan epinefrin, yang berpengaruh pada tekanan darah, pada 15 laki-laki dengan tipe kepribadian A dan 15 orang laki-laki dengan tipe kepribadian B pada saat istirahat dan pada situasi nonkompetitif. Pengukuran kadar norepinefrin dan epinefrin dilakukan sebelum, pada saat, dan setelah berpartisipasi dalam kompetisi nonfisik. Pada saat kompetisi, kadar norepinefrin pada kelompok kepribadian tipe A meningkat $30 \%$ di atas rata-rata, sedangkan kelompok lainnya tidak berubah; konsentrasi epinefrin cenderung tidak berubah pada kedua kelompok. ${ }^{11}$ Disimpulkan bahwa kelompok kepribadian tipe A 
cenderung mempunyai tekanan darah yang lebih tinggi pada situasi yang kompetitif.

Penelitian hubungan tipe kepribadian A dengan tekanan darah saat operasi bypass koroner dilakukan pada Desember 1972 hingga Februari 1975, terhadap 56 lakilaki dan 3 perempuan dengan usia rata-rata 51 tahun. Oklusi pembuluh darah $>50 \%$ ditentukan oleh minimal 1 orang kardiolog dan 1 orang radiolog melalui angiografi koroner, pengukuran tekanan darah awal menggunakan sfigmomanometer, penentuan kepribadian tipe A dengan menggunakan kuesioner standar Rosenman dan Friedman oleh seorang psikiater sebelum operasi. Observasi terhadap perubahan tekanan darah selama operasi dipantau dengan osiloskop. Penelitian ini menemukan hubungan yang bermakna antara peningkatan tekanan darah sistolik saat operasi dan kepribadian tipe A (nilai $\mathrm{p}<0,05$ ). Data mendukung bahwa kepribadian tipe A mempunyai hipereaktivitas otonom. Selain itu, karena penelitian ini dilakukan dalam keadaan anestesi umum, kemungkinan peningkatan tekanan darah oleh hal-hal yang disadari dapat disingkirkan. ${ }^{12}$

Beberapa penelitian lain memberi hasil yang berbeda, tidak ada hubungan antara perubahan sistem simpatis maupun tekanan darah dengan tipe kepribadian A karena sampel pada penelitian ini yang berusia relatif lebih muda dibandingkan penelitian lainnya. ${ }^{7}$ Penelitian menguji hipotesis bahwa kepribadian tipe A berhubungan dengan peningkatan denyut jantung dan sistem simpatis sebagai respons terhadap stressor mental dan fisik pada 45 responden (19 laki-laki dan 26 perempuan dengan rerata usia $29 \pm 8,7$ tahun) tanpa penyakit kronis dan tidak sedang mengonsumsi obat-obatan. Penelitian tersebut tidak menemukan perbedaan yang bermakna pada reaksi simpatis atau hemodinamik antara ketiga jenis stressor (tes lisan, isometric handgrip dan cold pressure) pada kelompok kepribadian tipe A. ${ }^{7}$

Penelitian hubungan tipe kepribadian A dan tekanan darah dilakukan pada sekitar 1.668 anak-anak multietnik usia sekolah. Tekanan darah diperiksa pada tahun 1978 dan setiap 2 tahun antara tahun 1987 - 1990. Usia ratarata sampel saat pertama kali pemeriksaan adalah 8 tahun. Anak laki-laki cenderung berkepribadian A dibandingkan anak perempuan dan kepribadian tipe-A secara potong lintang tidak berhubungan dengan peningkatan tekanan darah. Namun, penelitian ini tidak membandingkan tekanan darah antara orang dengan kepribadian tipe A dengan kepribadian tipe yang lain. ${ }^{13}$

Penelitian ini menemukan hubungan yang bermakna antara kepribadian tipe A dengan hipertensi setelah faktor-faktor risiko hipertensi lainnya disetarakan. Usia berpengaruh pada tekanan darah oleh karena proses degeneratif. Degenerasi pada usia lanjut menyebabkan kekakuan atau berkurangnya elastisitas pada pembuluh darah yang berdampak pada sistem hemodinamik.
Akibatnya terjadi kenaikan tekanan darah sistolik disertai penurunan tekanan darah diastolik pada usia lanjut. ${ }^{14}$ Perbedaan tekanan darah laki-laki dan perempuan dihubungkan dengan hormon seks. Estrogen menurunkan vascular resistance dengan cara meningkatkan kadar NO, meningkatkan kadar vasodilator endogen, menurunkan sintesis vasokonstriktor endogen, dan aktivasi channel kalium. Testosteron cenderung meningkatkan tekanan darah melalui beberapa mekanisme meliputi peningkatan kadar homosistein, endothelin-1, dan katekolamin. 15

Individu dengan orangtua penderita hipertensi berisiko dua kali lebih besar untuk menderita hipertensi daripada individu yang tidak mempunyai riwayat keluarga penderita hipertensi. Pada $70-80 \%$ kasus hipertensi primer didapatkan riwayat hipertensi dalam keluarga. Hipertensi juga banyak dijumpai pada penderita kembar monozigot (satu telur), apabila salah satu menderita hipertensi. ${ }^{10,12}$ Studi hubungan genetik telah mengidentifikasi polimorfisme dalam beberapa gen misalnya angiotensinogen, alfa-adducin, beta dan DA-adrenergik reseptor, dan subunit 3-beta dari protein G. Beberapa studi genetik telah memfokuskan pada beberapa genom yang mungkin berkontribusi pada hipertensi. Namun, belum ada kelainan genetik yang terbukti bertanggung jawab terhadap kejadian hipertensi pada populasi umum. ${ }^{9}$

Peningkatan asupan garam menyebabkan peningkatan volume ekstraseluler sehingga terjadi peningkatan tekanan arteri dan terjadi umpan balik negatif berupa penurunan renin dan angiotensin, penurunan retensi air dan garam dalam ginjal yang mengembalikan volume ekstraseluler dan tekanan arteri hampir ke nilai normal. Apabila sistem renin-angiotensin berfungsi normal, peningkatan tekanan arteri tidak lebih dari $4-6 \mathrm{mmHg}$ terhadap kenaikan asupan garam sebanyak 50 kali lipat. Bila sebaliknya, akan menyebabkan kenaikan tekanan sekitar 10 kali lebih banyak, kadang-kadang meningkat sebanyak 50 sampai $60 \mathrm{mmHg}$. ${ }^{16}$

Rokok mengakibatkan vasokonstriksi pembuluh darah perifer dan pembuluh di ginjal sehingga terjadi peningkatan tekanan darah. Hal ini disebabkan oleh zat-zat yang terkandung dalam asap rokok. Gas CO menggantikan tempat oksigen di hemoglobin, mengganggu pelepasan oksigen, dan mempercepat aterosklerosis (pengapuran atau penebalan dinding pembuluh darah). Nikotin akan menyebabkan peningkatan tekanan darah karena nikotin akan diserap oleh pembuluh darah kecil dalam paru-paru dan diedarkan oleh pembuluh darah hingga ke otak. Akibatnya, otak akan bereaksi terhadap nikotin dengan memberi sinyal pada kelenjar adrenal untuk melepas efinefrin (adrenalin). ${ }^{17}$

Obesitas berpengaruh pada peningkatan volume darah sekuncup serta peningkatan tahanan perifer pembu- 
luh darah sehingga meningkatkan tekanan darah. Peningkatan kadar insulin dan aldosteron dalam plasma penderita obesitas menyebabkan retensi natrium $(\mathrm{Na})$ dalam darah yang mengakibatkan terjadinya peningkatan volume darah dan akhirnya menyebabkan hipertensi. ${ }^{15}$

Temuan penelitian ini dibatasi oleh beberapa hal. Pertama, desain studi potong lintang membatasi kemampuan meneliti hubungan temporal sebab-akibat antara kepribadian tipe A dengan hipertensi. Kedua, bias seleksi tidak dapat disingkirkan karena pengambilan sampel secara nonrandom sehingga membatasi aplikasi langsung temuan penelitian ini dari sampel ke populasi di wilayah kerja Puskesmas Kelurahan Joglo II. Ketiga, non-differential misclassification masih belum dapat disingkirkan karena keterbatasan validasi instrumen maupun reabilitas interobserver maupun intraobserver. Keempat, bias perancu belum dapat disingkirkan karena dalam penelitian ini, stres yang merupakan faktor risiko hipertensi dan sering dikaitkan dengan kepribadian tipe A, tidak dapat diukur dengan pasti.

\section{Kesimpulan}

Penelitian ini mendapatkan hubungan kepribadian tipe A dan hipertensi pada usia dan jenis kelamin yang disetarakan. Hubungan tersebut bermakna secara statistik antara kepribadian tipe A dan hipertensi. Pasien yang memiliki kepribadian tipe A mempunyai peningkatan kerja sistem saraf simpatis dan hemodinamik tubuh yang memengaruhi denyut jantung dan tekanan darah. Penelitian eksperimental dan bukti klinis menunjukkan central neural origin dari peningkatan sistem simpatis.

\section{Saran}

Dibutuhkan studi lanjut dengan desain lain, seperti kasus kelola, kohort, maupun eksperimental untuk mengetahui dengan lebih pasti bagaimana hubungan antara kepribadian tipe A dan hipertensi. Mengenali tipe kepribadian masing-masing, terutama bagi yang mempunyai kepribadian tipe A dapat mengendalikan kepribadian baik dengan behavioral therapy atau konseling. Hal tersebut diharapkan menjadi salah satu strategi menurunkan risiko hipertensi pada pasien yang berobat di Puskesmas Kelurahan Joglo II, Jakarta Barat, khususnya, maupun masyarakat Indonesia umumnya.

\section{Daftar Pustaka}

1. Setiawan Z. Prevalensi dan determinan hipertensi di Pulau Jawa. Kesmas Jurnal Kesehatan Masyarakat Nasional [online]. 2006 Oktober [diakses tangga 30 April 2012\}; 1 (2): 57-62. Diunduh dalam: http://www.fkm.ui.ac.id/index.php?option=com $\cdot$ content $\&$ task $=v i e w \& i d=56 \&$ Itemed $=70$.

2. World Health Organization. Mean systolic blood pressure [cited 2012 April 30]. Available from: http://www.who.int/gho/ncd/risk_factors/bloodpressuremeantext/en/index.html.
3. Tse H. Hypertension in Asia: what are the issues and opportunities to address the epidemic? [serial on internet]. Physician's Academy for Cardiovascular Education (PACE); 2011 [cited 2012 Jun 25]. Available from: http://www.pace-cme.org/files/Download-slides-as-PDF-3-142012_20-23-22.pdf.

4. Kementerian Kesehatan Republik Indonesia. Hindari hipertensi, konsumsi garam 1 sendok teh per hari [diakses tanggal 21 Agustus 2012]. Diunduh dalam: http://depkes. go.id/index.php/berita/press-release/263-hindari-hipertensi-konsumsi-garam-1-sendok-teh - perhari.html.

5. Hamid. Seminar the $5^{\text {th }}$ scientific meeting on hypertension 2011. In: Dhuha S, ed. Astaga, prevalensi hipertensi di Indonesia sangat tinggi. 2011 [Diakses tanggal 3 Mei 2012]. Available from: http://www.today.co.id/read/2011/02/26/13140/astagaprevalensi_hipertensi _di_indonesia_sangat_tinggi.

6. Puskesmas Kelurahan Joglo II. Laporan tahunan tahun 2011. Jakarta: Puskesmas Kelurahan Joglo II; 2012.

7. Schroeder KE, Narkiewicz K, Kato M, Pesek C, Phillips B, Davison D, et al. Personality type and neural circulatory control. Hypertension [serial on internet]. 2000 Nov [cited 2012 May 3]; 36 (5): 830-3. Available from: http://hyper. ahajournals.org/content/36/5/830.full.

8. Al-Asadi JN. Type A behaviour pattern: is it a risk factor for hypertension? Eastern Mediterranean Health Journal [serial on internet]. 2010 [cited 2012 September 18]; 16(7): 740-5. Available from: http://applications.emro.who.int/emhj/V16/07/16_7_2010_0740_0745.pdf

9. Irvine J, Garner DM, Craig HM, Logan AG. Prevalence of type A behavior in untreated hypertensive individuals. Hypertension [serial on internet]. 1991 [cited 2012 September 19]; 18 (1): 72-8. Available from: http://hyper.ahajournals.org/content/18/1/72.

10. Newlin DB, Levenson RW. Cardiovascular responses of individual with Type A Behavior and parental coronary heart disease. Journal of Psychosomatic Research [serial on internet]. 1982 [cited 2012 September 7]; 26 (4): 393-402. Available from: http://istsocrates.berkeley.edu/ ucbpl/docs/18-Cardiovascular\% 20Responses82.pdf

11. Friedman M, Byers SO, Diamant J, Rosenman RH. Plasma catecholamine response of coronary-prone subjects (type A) to a specific challenge. Metabolism [serial on internet]. 1975 Feb [cited 2012 September 20]; 24 (2): 205-10. Available from: http://www. sciencedirect.com /science/article/pii/0026049575900220

12. Kahn JP, Kornfeld DS, Frank KA, Heller SS, Hoar PF. Type A behavior and blood pressure during coronary artery bypass surgery. Psychological Medicine [serial on internet]. 1980 Jul [cited 2012 May 2]; 42 (4): 40714. Available from: http://www.psychosomaticmedicine. org/content/42/4/407.full.pdf

13. Lee DJ, Gomez-Marin O, Prineas RJ. Type A Behavior pattern and change in blood pressure from childhood to adolescence. American Journal of Epidemiology [serial on internet]. 1996 Jan [cited 2012 September 19]; 143 (1): 63-72. Available from: http://aje.oxfordjournals.org/content/143/1/63.full.pdf

14. Kotchen TA. Hypertensive vascular disease. In: Fauci AS, Kasper DL, Longo DL, Braunwald E, Hauser SL, James JL, et al., editors. Harrison's principles of internal medicine. $17^{\text {th }}$ ed. New York: McGraw Hill, 2008: p. 1549-54. 
Chitrayana, Feby, Lauren, Rumawas, Kidarsa \& Sutrisna, Kepribadian Tipe A dan Risiko Hipertensi

15. Dubey RK, Oprail S, Imthrun B, Jackson KE. Sex hormones and hypertension. Cardiovascular Research [serial on internet\}. 2002 [cited 2012 May 8]; 53 (3): 688-708. Available from: oxfordjournals.org/content/53/3/688.full.pdf.
16. Guyton AC, John EH. Buku ajar fisiologi kedokteran. Edisi ke-9. Jakarta: EGC; 1997.

17. Feist J, Feist GJ. Pendahuluan untuk teori kepribadian. Edisi ke-3. Yogyakarta: Pustaka Pelajar; 2008. 